Article

\title{
Exploring an Integrated Manure-Seawater System for Sustainable Cyanobacterial Biomass Production
}

\author{
Mekiso Yohannes Sido ${ }^{1,2}$ \\ 1 Key Laboratory of Agricultural Water Resources, Center for Agricultural Resources Research, Institute of \\ Genetics and Developmental Biology, Chinese Academy of Sciences, 286 Huaizhong Road, Shijiazhuang \\ 050021,China; meksido4@gmail.com or mekiso.y@sjziam.ac.cn \\ 2 University of Chinese Academy of Sciences, Beijing 100039, China
}

Received: 29 July 2019; Accepted: 30 August 2019; Published: 16 September 2019

\begin{abstract}
Cyanobacterial biomass is important for biofuel and biofertilizer, however, biomass production requires expensive chemical growth nutrients. To address this issue, we explored the use of inexpensive growth nutrient media from an integrated manure-seawater system for cyanobacterial biomass production. Salt-tolerant cyanobacterial strain $\mathrm{HSaC}$ and salt-sensitive cyanobacterial strain LC were tested to evaluate the potential of integrated manure-seawater media for sustainable cyanobacterial biomass production. As a prerequisite for seawater experiments, strain $\mathrm{HSaC}$ was grown at different $\mathrm{NaCl}$ concentrations $(0 \mathrm{mM}, 60 \mathrm{mM}, 120 \mathrm{mM}, 180 \mathrm{mM}, 240 \mathrm{mM}$ and $300 \mathrm{mM})$ to identify the optimum salt concentration. The highest biomass yield and photosynthetic pigment contents were obtained at $120 \mathrm{mM} \mathrm{NaCl}$ concentration. The highest exo-polysaccharide (EPS) content was obtained at $180 \mathrm{mM} \mathrm{NaCl}$ concentration. The treatments for the manure-seawater media were cow manure, pig manure, chicken manure and BG11, each with distilled water, diluted seawater and non-diluted seawater. The highest biomass and photosynthetic pigment yield for cyanobacterial strains LC and $\mathrm{HSaC}$ were obtained from $0.5 \mathrm{dS} / \mathrm{m}$ and $10 \mathrm{dS} / \mathrm{m}$ diluted seawater integrated with cow manure, respectively, but pig and chicken manure performed poorly. Overall, the biomass production and photosynthetic pigment results from cow manure-seawater were relatively better than those from the reference media (BG11). Based on the current findings, it is concluded that the growth nutrients from integrated cow manure-seawater can wholly substitute for the BG11 without affecting cyanobacterial growth, thereby reducing the usage of expensive chemical growth media. Thus, the results of study help to enhance the biomass production of both salt-sensitive and salt-tolerant cyanobacteria for sustainable biofuel and biofertilizer production.
\end{abstract}

Keywords: cyanobacteria; biomass; seawater; manure; BG11

\section{Introduction}

Cyanobacteria (blue green algae) are a diverse group of prokaryotic oxygen-generating photosynthetic micro-organisms that conduct photosynthesis in a very similar way as higher plants [1]. Cyanobacteria are able to produce useful metabolic products, such as pigment for feed additives, fatty acids, proteins and other nutrients [2]. Because of the continuous increase in the global human population and degradation of natural resources, meeting the demand for obtaining sustainable food and energy without creating environmental problems has become a topic of concern. Therefore, cyanobacteria have recently emerged as a potential candidate that might meet the above mentioned criteria due to its capacity to effectively harvest natural solar energy, utilize water, $\mathrm{CO}_{2}$ and nutrients, and convert them into biomass [3]. The biomass of cyanobacteria can be used for many purposes, such as food production, biofertilizer for crop production and soil fertility, biofuels (energy), cosmetics, and medical applications [3]. Cyanobacterial and microalgal biomasses have become important 
substances for feed, biofuel, chemical production, and agricultural crop production that aims to meet the global food demand. In addition, because of their photoautotrophic nature, they are cultivated to generate important products, such as proteins, pigments, fatty acids, vitamins, and polysaccharides [4].

Interest in the production of biomass from cyanobacteria and microalgae for the extraction of bio-fuels, bio-fertilizer, animal feed and other bio-products is increasing. Although microalgae are considered as a potential alternative to meet some of the global demands, a decrease in the cost of biomass production cost is required to actually achieve this potential [5]. Spirulina sp. is a filamentous cyanobacteria with a relatively high cell growth rate, which makes it ideal for biomass production [6]. The role of Spirulina platensis biomass in poultry manure treatment and biogas production was studied by Mahadevaswamy and Venkataraman [7] through an integrated anaerobic digestion (AD) and microalgae cultivation system.

Nowadays, the interest in microalgal mass culturing technology is focused on small-scale cultivation, such as for commercial production and production for human food, as well as large-scale production, for example, for renewable energy and environmentally sustainable approaches [5]. A major problem in algal mass cultivation for the production of sustainable biofuels is the need for high phosphate and nitrogen nutrients. To address such nutrient demand problems, studies have been conducted on anaerobic digestion effluent (ADE) as an alternative, cost-effective nutrient supplement [8-10]. For the production of microalgal biomass, the waste of animals such as poultry litter digester efflux (PLDE) can be used as an alternative culture medium source, because theycontain all the necessary nutrients, and therefore might be an attractive low-cost microalgal growth media [11]. Developing economical and sustainable biomass production technology is likely to make microalgal and cyanobacterial biomasses someof the most useful substances in bioindustries [12]. Experiments on the treatment of anaerobically digested pig waste effluent by immobilized algae [13], suspended micro-algae in large pond systems ([14-16]) and algal mass-cultures [17] were conducted for biomass production. In some studies [18-20], the researchers tested agricultural fertilizer as a possible low-cost growth medium alternative to Zarrouk's medium [21] for algal biomass production.

Considering the significantly high microalgal biomass production from anaerobic digestion effluent of cattle manure [22,23], extracts of poultry manure [11], and pig waste effluent $[9,24]$, and increased spirulina cell growth rates in hypersaline medium [25], in this study we explored potential cyanobacterial growth media using integrated animal manure and seawater as organic and inorganic nutrient sources, respectively. Although cyanobacterial biomasses are very important for biofuel and biofertilizer production, mass culturing needs expensive chemical growth media, such as BG11. Although there is currently great interest in developing economically feasible technologies for cyanobacterial biomass production, research on using integrated manure-seawater systems as a cost effective alternative growth nutrient source for cyanobacterial biomass production is not well reported. Therefore, the aim of the current study was to develop economically feasible cyanobacterial growth media from an integrated manure-seawater system for sustainable cyanobacterial biomass production. The results obtained from the current research work will be used to develop cyanobacterial mass cultivation technology for biofuel and biofertilizer production in a cost-effective way.

\section{Materials and Methods}

\subsection{Evaluating a Cyanobacterial Strain (HSaC) at Different Salt Concentrations in BG11 Medium}

We evaluated the growth performance of the salt tolerant cyanobacterial strain $\mathrm{HSaC}$ at different salt concentrations in liquid media to determine the optimum salt concentration for high biomass production. Two cyanobacterial strains ( $\mathrm{HSaC}$ and $\mathrm{LC}$ ) were obtained from the Center for Agricultural Resources Research, Institute of Genetics and Developmental Biology, Chinese Academy of Sciences, Department of Microbial Ecology, and were previously isolated from soils of the North China plain. The results from the $\mathrm{NaCl}$ salt experiment were perquisite for the experiment that was conducted on seawater and animal manure media. The treatments for $\mathrm{NaCl}$ salt concentrations were: $0 \mathrm{mM}, 60 \mathrm{mM}$, 
$120 \mathrm{mM}, 180 \mathrm{mM}, 240 \mathrm{mM}$ and $300 \mathrm{mM}$ in BG11 media. Treatments were replicated 3 times, and the total number of experiments was 18 . The experiment was conducted using a completely randomized design (CRD). Cyanobacteria was grown in flasks using an orbital shaker (180 rpm), and incubated at a temperature of $25.5^{\circ} \mathrm{C}$. The growth culture was subject to light (2600 lux) for $8 \mathrm{~h}$ light and $16 \mathrm{~h}$ of dark.

\subsection{Measurement of Biomass, Exo-Polysaccharides (EPSs) and Photosynthetic Pigments}

For biomass measurement, $50 \mathrm{~mL}$ of cyanobacterial growth culture was collected and centrifuged at $5000 \mathrm{rpm}$ for $10 \mathrm{~min}$. After the liquid supernatant was discarded, the biomass was exposed to room temperature on aluminum foil to reduce the water content, and then the biomass was measured as a fresh weight using the weight balance. In order to determine the exo-polysaccharide (EPS) content, an extract was taken from the fresh biomass using the formaldehyde- $\mathrm{NaOH}$ method as described by [26], and then the polysaccharide content in the extract was measured using the phenol-sulfuric acid method as described by [27]. To measure the photosynthetic pigments (chlorophyll a and carotenoids), extraction and spectrophotometric absorbance measurements were conducted using the protocol described by [28], and the chlorophyll a content was calculated from the absorbance value using the formula Chla $[\mu \mathrm{g} / \mathrm{mL}]=12.9447(\mathrm{~A} 665-\mathrm{A} 720)$ as described by [29]. Carotenoid content was calculated using the formula, carotenoids $[\mu \mathrm{g} / \mathrm{mL}]=[1000(\mathrm{~A} 470-\mathrm{A} 720)-2.86(\mathrm{Chla}[\mu \mathrm{g} / \mathrm{mL}])] / 221$ as described by [30].

\subsection{Development of Growth Media from Animal Manure and Seawater}

The manure-seawater experiment was conducted after we determined the growth performance of cyanobacterial strain $\mathrm{HSaC}$ at different $\mathrm{NaCl}$ salt concentrations. Then, inexpensive growth media for cyanobacteria were developed by integrating animal manure and seawater. Briefly, fresh animal manures, namely, cow manure, pig manure and chicken manure, were obtained from a farm in the Northern China Plain, and then, the manures were dried at room temperature to protect against nutrient loss. After the manures had dried, they were ground, and then sieved with $2 \mathrm{~mm}$ diameter mesh. The sieved manure was measured out based on $1 \mathrm{~g}$ of manure to $10 \mathrm{~mL}$ of distilled water, and then stirred with magnetic bars at $710 \mathrm{rpm}$ for $1 \mathrm{~h}$ at room temperature, and autoclaved at $121^{\circ} \mathrm{C}$ for $30 \mathrm{~min}$ to kill all the microbes in the manure. After autoclaving, the manures were centrifuged using $5000 \mathrm{rpm}$ at room temperature for $5 \mathrm{~min}$ with autoclaved tubes to collect the supernatant. The collected supernatants were filtered with sterilized Whatman filter paper, and then the filtrates were sterilized with UV for $1 \mathrm{~h}$ and stored as stock solution at $4{ }^{\circ} \mathrm{C}$. Both natural and artificial seawater were also autoclaved prior to the experiments. The first animal manure-seawater experiment was conducted in 3 replicates with CRD to identify the best manure-seawater media for the growth of cyanobacterial strain $\mathrm{HSaC}$. The integrated manure-seawater treatments were: $\mathrm{PD}=$ pig manure with distilled water, P10 = pig manure with diluted $(10 \mathrm{dS} / \mathrm{m})$ seawater, PS = pig manure with seawater, $\mathrm{CD}=$ cow manure with distilled water, $\mathrm{C} 10=$ cow manure with diluted $(10 \mathrm{dS} / \mathrm{m})$ seawater, $\mathrm{CS}=$ cow manure with seawater, BGD = reference cyanobacterial growth media (BG11) with distilled water, BG10 $=$ BG11 media with diluted $(10 \mathrm{dS} / \mathrm{m})$ seawater, BGS $=$ BG11 media with seawater, $\mathrm{ChD}=$ chicken manure with distilled water, $\mathrm{Ch} 10=$ chicken manure with diluted $(10 \mathrm{dS} / \mathrm{m})$ seawater, and $\mathrm{ChS}=$ chicken manure with seawater. After we identified the best animal manure in reference to the BG11 media, we conducted a second experiment comparing both natural and artificial seawater with the selected best manure (cow manure) to investigate whether natural seawater can substitute for artificial seawater. The treatments were performed in 3 replicates using CRD as follows: DW $=$ cow manure with distilled water, $10 \mathrm{~N}=$ cow manure with diluted $(10 \mathrm{dS} / \mathrm{m})$ natural seawater, $10 \mathrm{~A}=\mathrm{cow}$ manure with diluted $(10 \mathrm{dS} / \mathrm{m})$ artificial seawater, $\mathrm{SN}=$ cow manure with natural seawater, and $\mathrm{SA}=$ cow manure with artificial seawater. For salt-sensitive cyanobacterial biomass production, we tested salt-sensitive cyanobacterial strain LC. Briefly, the treatments were performed in 3 replicates using CRD as follows: $\mathrm{DW}=$ cow manure with distilled water, $0.5 \mathrm{dS}=$ cow manure with diluted $(0.5 \mathrm{dS} / \mathrm{m})$ seawater, and $1.5 \mathrm{dS}=$ cow manure with diluted $(1.5 \mathrm{dS} / \mathrm{m})$ seawater. 


\subsection{Nutrient Composition of Seawater and Manure}

Natural seawater was obtained from the Bohai Sea in the North China Plain, and its elemental nutrient content and heavy metal concentration were found in a previous study [31,32]. The artificial seawater was prepared by dissolving $1 \mathrm{~g}$ of sea-salt in $30 \mathrm{~mL}$ of distilled water. The sea-salt was obtained from Guangzhou Yier BE Co., Ltd., Guangzhou city, Guangdong province, China, and contained $\mathrm{Mg}^{2+} \mathrm{Na}^{+}, \mathrm{K}^{+}, \mathrm{Sr}^{2+}, \mathrm{Cl}^{-}, \mathrm{SO}_{4}{ }^{2+}, \mathrm{HCO}^{-}, \mathrm{Br}^{-}, \mathrm{Cu}, \mathrm{Mo}, \mathrm{Rb}, \mathrm{Be}, \mathrm{Co}, \mathrm{Ni}, \mathrm{I}, \mathrm{As}, \mathrm{W}, \mathrm{Se}, \mathrm{Ze}, \mathrm{Cr}$, and $\mathrm{Mn}$. The nutrient composition of animal manures, namely, cow manure, pig manure and chicken manure has been presented in previous studies (Tables 1 and 2).

Table 1. The nutrient contents of cow manure, pig manure and chicken manure in China (Source: Nutrient Contents in Main Animal Manures in China. J. Agro-Environ. Sci. [33]).

\begin{tabular}{cccc}
\hline Nutrient Constituent & Cow Manure & Pig Manure & Chicken Manure \\
\hline $\mathrm{N}(\%)$ & 1.56 & 2.28 & 2.08 \\
$\mathrm{P}_{2} \mathrm{O}_{5}(\%)$ & 1.49 & 3.97 & 3.53 \\
$\mathrm{~K}_{2} \mathrm{O}(\%)$ & 1.96 & 2.09 & 2.38 \\
$\mathrm{Zn}\left(\mathrm{mg} \mathrm{kg}^{-1}\right)$ & 138.6 & 663.3 & 306.6 \\
$\mathrm{Cu}\left(\mathrm{mg} \mathrm{kg}^{-1}\right)$ & 48.5 & 488.1 & 78.2 \\
\hline
\end{tabular}

Table 2. Elemental composition of cow (dairy) manure, pig (swine) manure and chicken (poultry) manure presented in different reports (source: for dairy manure, [23]; for swine manure, [9]; and for poultry manure [11]).

\begin{tabular}{cccc}
\hline Element & $\begin{array}{c}\text { Cow (Dairy) Manure } \\
\left(\mathbf{m g ~ L}^{-\mathbf{1}}\right)\end{array}$ & $\begin{array}{c}\text { Pig (Swine) Manure } \\
\left(\mathbf{m g ~ L}^{-\mathbf{1}}\right)\end{array}$ & $\begin{array}{c}\text { Chicken (Poultry) } \\
\left.\text { Manure (mg L }^{-\mathbf{1}}\right)\end{array}$ \\
\hline $\mathrm{Ca}$ & 860 & 170 & 173 \\
$\mathrm{Mg}$ & 260 & 100 & 21.5 \\
$\mathrm{Si}$ & 115 & - & 25.7 \\
$\mathrm{Fe}$ & 20.6 & 16.5 & 22.4 \\
$\mathrm{Al}$ & 20.6 & 7.3 & 6.92 \\
$\mathrm{Mn}$ & 9.2 & 2.7 & 4.57 \\
$\mathrm{~B}$ & 1.6 & - & 2.87 \\
$\mathrm{Cd}$ & 0.08 & 0.009 & 0.989 \\
$\mathrm{~Pb}$ & 0.05 & 0.036 & 2.76 \\
$\mathrm{Ni}$ & 0.09 & - & 1.33 \\
$\mathrm{Mo}$ & 0.06 & 0.11 & 1.76 \\
\hline
\end{tabular}

\subsection{Statistical Analysis}

The collected data for all treatments were subjected to statistical ANOVA using statistical analysis software (SAS) version 9.2. ANOVA tests were performed, and comparison of means was carried out using Tukey's test at the probability level of $5 \%$.

\section{Results}

\subsection{Effect of $\mathrm{NaCl}$ Concentration on Growth of Cyanobacterial Strain $\mathrm{HSaC}$}

The biomass of cyanobacterial strain $\mathrm{HSaC}$ was significantly $(p<0.05)$ influenced by the $\mathrm{NaCl}$ concentration. The biomass of $\mathrm{HSaC}$ increased as the $\mathrm{NaCl}$ salt concentration increased up to $120 \mathrm{mM}$, but further increases in salt concentration resulted in a decrease in biomass production. Accordingly, the highest $(30.52 \mathrm{mg} / \mathrm{mL})$ biomass yield was obtained at $120 \mathrm{mM} \mathrm{NaCl}$ concentration, while the lowest $(10.60 \mathrm{mg} / \mathrm{mL})$ amount was obtained at $0 \mathrm{mM}$ (Figure 1$)$. 


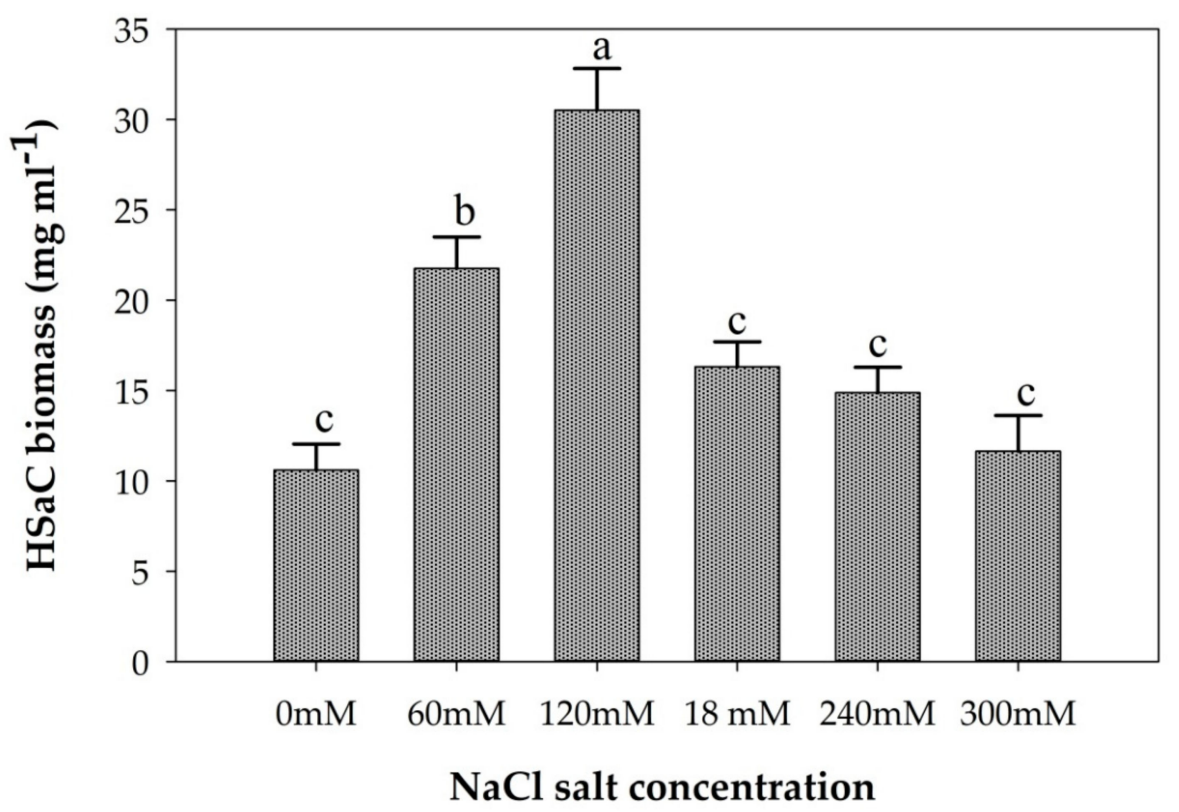

Figure 1. Cyanobacterial strain $\mathrm{HSaC}$ biomass $(\mathrm{mg} / \mathrm{mL})$ in different $\mathrm{NaCl}$ salt concentrations $(0 \mathrm{mM}$, $60 \mathrm{mM}, 120 \mathrm{mM}, 180 \mathrm{mM}, 240 \mathrm{mM}$ and $300 \mathrm{mM}$ ). The error bars represent standard deviation (SD). The data are the mean of the three replicates. Differing letters indicate significant differences in the means of $\mathrm{HSaC}$ cyanobacterial biomass in pair-wise comparisons (Tukey's test $p<0.05$ ) for each treatment by LSD.

The exo-polysaccharide (EPS) content of the HSaC culture showed a significant $(p<0.05)$ difference among the $\mathrm{NaCl}$ salt concentrations. Unlike biomass and photosynthetic pigment content, the highest $(0.84 \mathrm{mg} / \mathrm{g})$ EPS content was obtained at $180 \mathrm{mM} \mathrm{NaCl}$ salt concentration, while the lowest content $(0.22 \mathrm{mg} / \mathrm{g})$ was at $0 \mathrm{mM}$ (Figure 2).

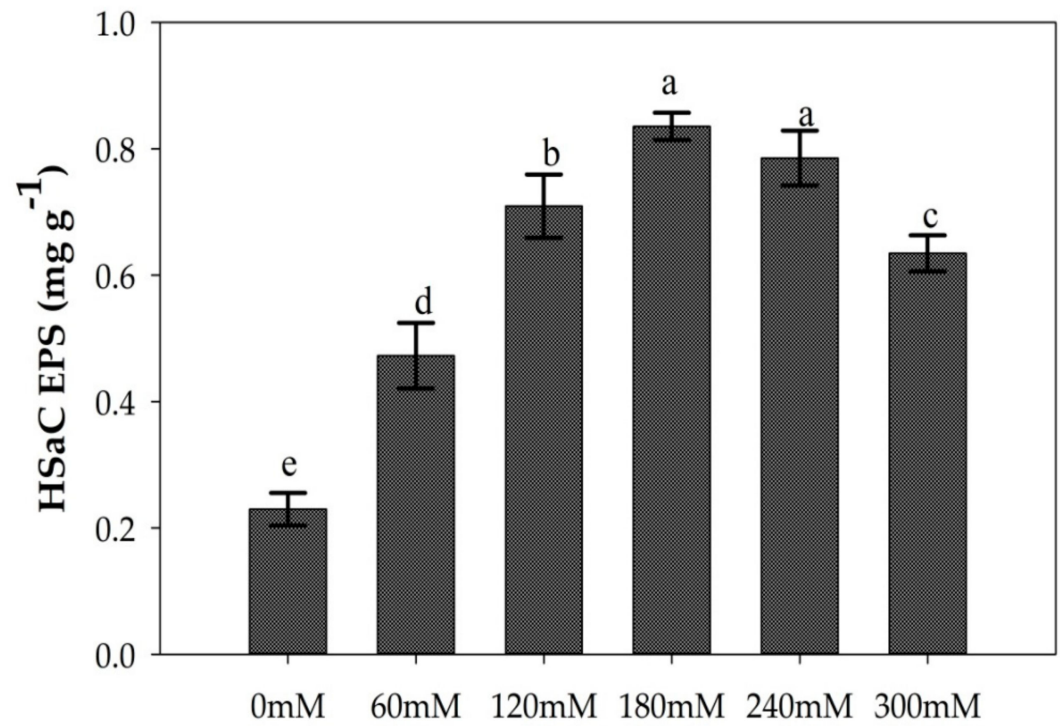

\section{$\mathrm{NaCl}$ salt concentration}

Figure 2. HSaC cyanobacterial exo-polysaccharide (EPS) content as influenced by different $\mathrm{NaCl}$ salt concentration ( $0 \mathrm{mM}, 60 \mathrm{mM}, 120 \mathrm{mM}, 180 \mathrm{mM}, 240 \mathrm{mM}$ and $300 \mathrm{mM})$. The error bars represent standard deviation (SD). The data are the mean of the three replicates. Differing letters indicate significant differences in the means of $\mathrm{HSaC}$ cyanobacterial exo-polysaccharide content pairwise comparisons (Tukey's test $p<0.05$ ) for each treatment by LSD. 
The photosynthetic pigment (chlorophyll a and carotenoid) content showed a significant $(p<0.05)$ difference among the $\mathrm{NaCl}$ salt concentrations. Accordingly, the highest chlorophyll a and carotenoid contents $(1.23 \mathrm{mg} / \mathrm{g}$ and $0.33 \mathrm{mg} / \mathrm{g}$, respectively) were obtained at $120 \mathrm{mM} \mathrm{NaCl}$, while the lowest chlorophyll a and carotenoid contents $(0.53 \mathrm{mg} / \mathrm{g}$ and $0.13 \mathrm{mg} / \mathrm{g}$, respectively) were obtained at $0 \mathrm{mM}$ (Figure 3 and Figure S1, respectively).

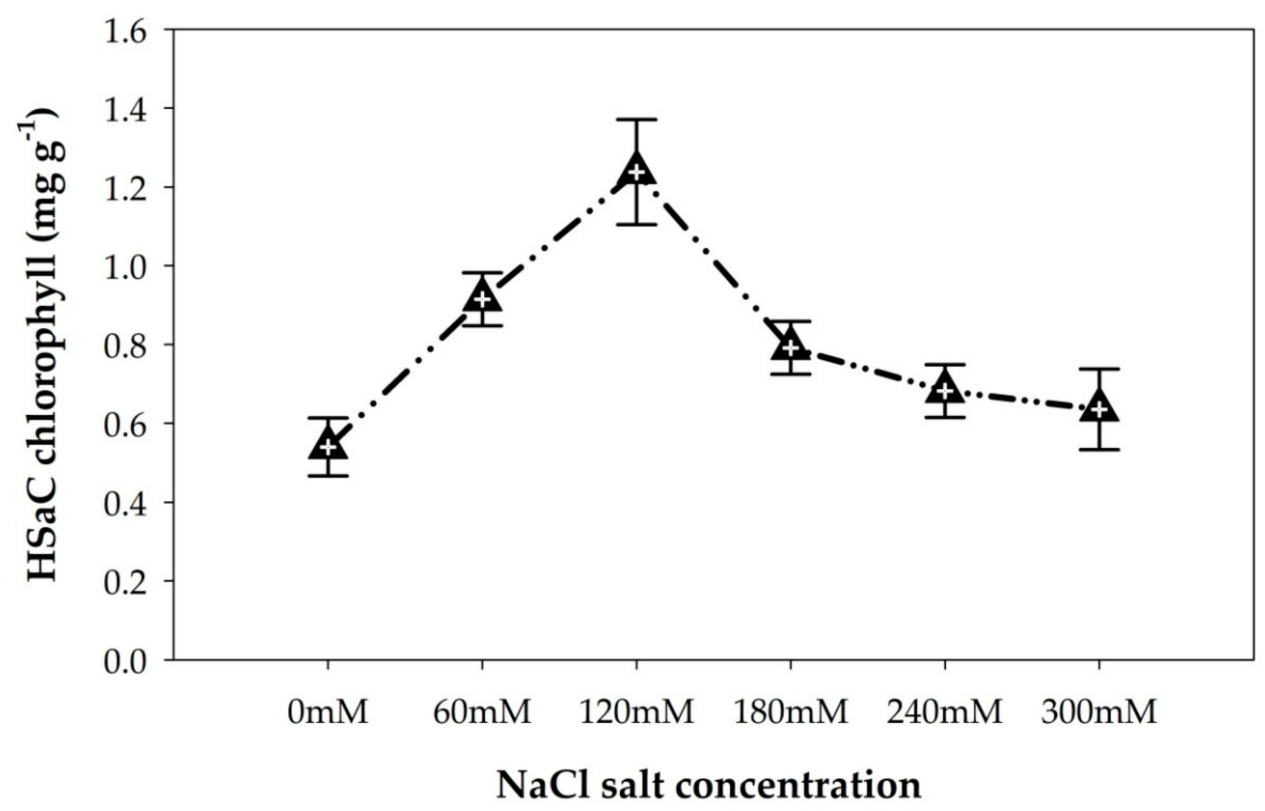

Figure 3. $\mathrm{HSaC}$ cyanobacterial chlorophyll content as influenced by different $\mathrm{NaCl}$ salt concentration (0 mM, $60 \mathrm{mM}, 120 \mathrm{mM}, 180 \mathrm{mM}, 240 \mathrm{mM}$ and $300 \mathrm{mM}$ ). The error bars represent standard deviation (SD). The data are the mean of three replicates.

\subsection{Growth Response of Cyanobacteria to Manure and Seawater Media}

Differences in $\mathrm{pH}$ were observed between cow manure, pig manure and chicken manure. Before the cyanobacteria were cultured, the chicken manure was slightly acidic ( $\mathrm{pH}$ 6.87), while pig manure and cow manure were basic ( $\mathrm{pH} 8.76$ and 9.43, respectively). After the cyanobacterial strain was grown for approximately 21 days, the $\mathrm{pH}$ value of the cultures increased for BG11, cow manure-seawater, and pig manure-seawater media, while there was no $\mathrm{pH}$ change in the chicken manure-seawater medium (Figure 4).

The cyanobacterial strain $\mathrm{HSaC}$ biomass production was significantly $(p<0.05)$ different among the integrated manure-seawater media. The highest $(33.26 \mathrm{mg} / \mathrm{mL})$ biomass was obtained from cow manure with diluted seawater $(10 \mathrm{dS} / \mathrm{m})$, while the lowest biomass was from chicken manure with all seawater treatments and pig manure with distilled water (Figure 5). The biomass yield obtained from BG11 with seawater was higher than that obtained from the pig and chicken manures with seawater (Figure 5). 


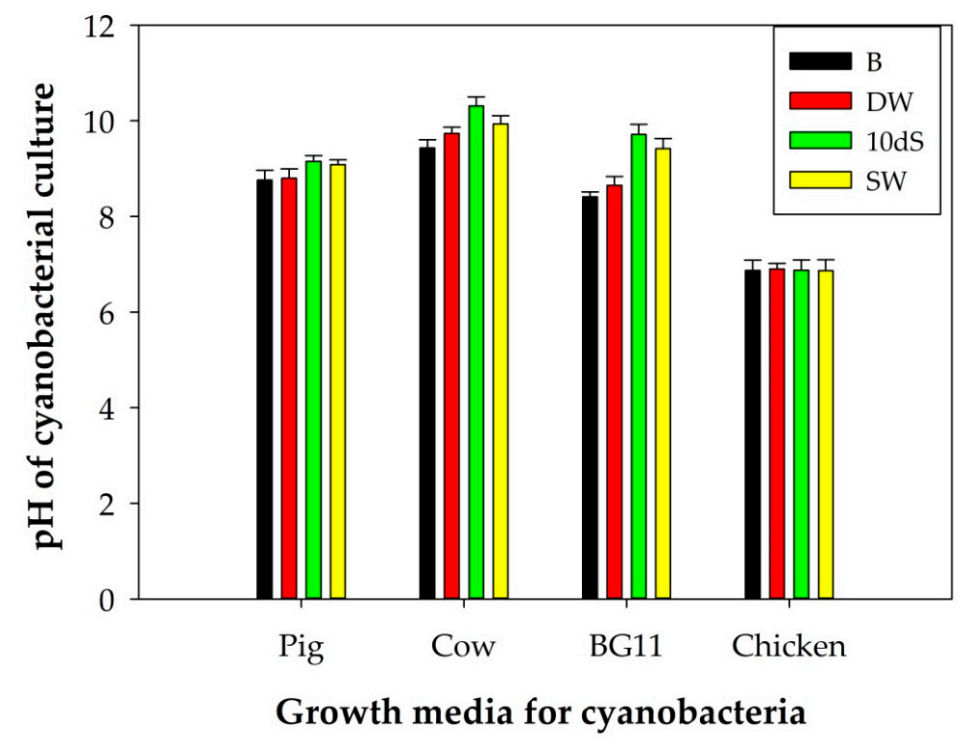

Figure 4. $\mathrm{pH}$ of cyanobacterial culture media before and after cyanobacterial growth. Pig = pig manure, cow $=$ cow manure, chicken = chicken manure, $\mathrm{B}=$ each manure before cyanobacteria were cultured, $\mathrm{DW}=$ distilled water, $10 \mathrm{dS}=$ diluted seawater at an EC of $10 \mathrm{dS} / \mathrm{m}$, and $\mathrm{SW}=$ seawater. The error bars represent standard deviations (SDs). The data are the mean of three replicates.

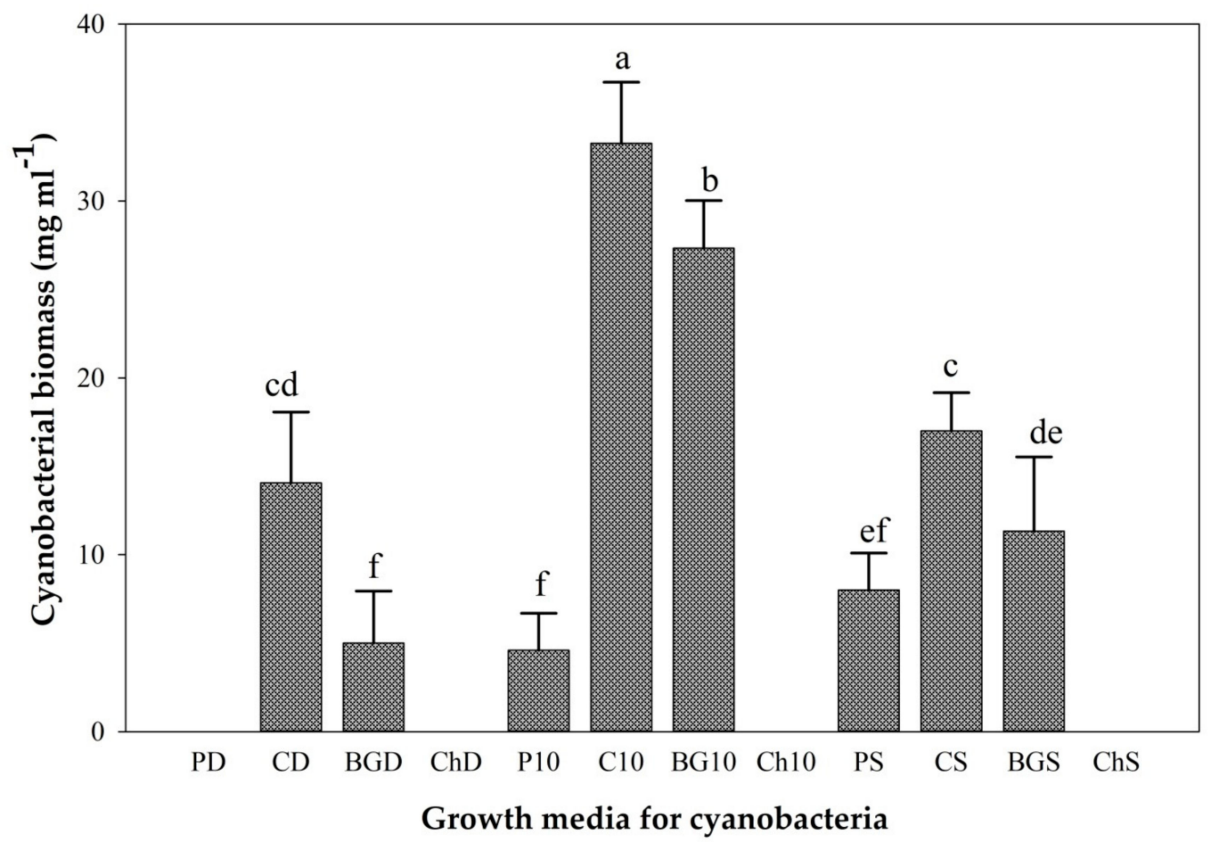

Figure 5. Effects of different animal manures and seawater dilution on $\mathrm{HSaC}$ cyanobacterial biomass. $\mathrm{PD}=$ pig manure in distilled water, $\mathrm{CD}=$ cow manure in distilled water, $\mathrm{BGD}=\mathrm{BG} 11$ in distilled water, $\mathrm{ChD}=$ chicken manure in distilled water, $\mathrm{P} 10=$ pig manure in diluted seawater (EC 10 $\mathrm{dS} / \mathrm{m}), \mathrm{C} 10=$ cow manure in diluted seawater $(10 \mathrm{dS} / \mathrm{m}), \mathrm{BG} 10=\mathrm{BG} 11$ in diluted seawater $(10 \mathrm{dS} / \mathrm{m})$, Ch10 = chicken manure in diluted seawater $(10 \mathrm{dS} / \mathrm{m}), \mathrm{PS}=$ pig manure in seawater, $\mathrm{CS}=$ cow manure in seawater, BGS = BG11 in seawater and ChS = chicken manure in seawater. The error bars represent standard deviations (SDs). The data are the mean of three replicates. Differing letters indicate significant differences in means of cyanobacterial biomass in pairwise comparisons (Tukey's test $p<0.05$ ).

The biomass production yield, and photosynthetic pigments (chlorophyll a and carotenoid) content for cyanobacterial strain HSaC did not show a significant $(p<0.05)$ difference between the cow manure with natural and artificial seawater treatments (10N and 10A, respectively) as shown 
in Figure 6, Figure 7 and Figure S2. On the other hand, a significant difference in biomass yield and chlorophyll a was observed between the natural seawater (SN) and artificial seawater (SA) treatments (Figures 6 and 7).

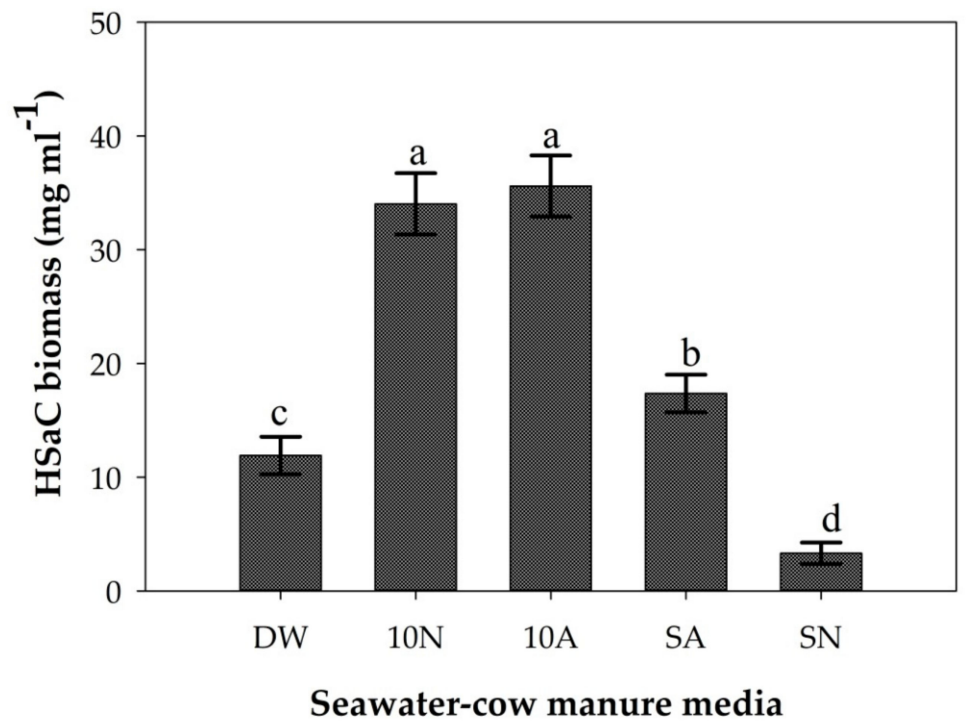

Figure 6. Effect of both natural and artificial seawater in cow manure media on HSaC cyanobacterial biomass. $\mathrm{DW}=$ distilled water with cow manure, $10 \mathrm{~N}$ = natural seawater $(\mathrm{EC}, 10 \mathrm{dS} / \mathrm{m})$ with cow manure, $10 \mathrm{~A}=$ artificial seawater $(\mathrm{EC}, 10 \mathrm{dS} / \mathrm{m})$ with cow manure, $\mathrm{SA}=$ artificial seawater with cow manure and $\mathrm{SN}=$ natural seawater with cow manure. The error bars represent standard deviation (SD). The data are the mean of three replicates. Differing letters indicate significant differences in means of HSaC cyanobacterial biomass in pairwise comparisons (Tukey's test $p<0.05$ ) for each treatment by LSD.

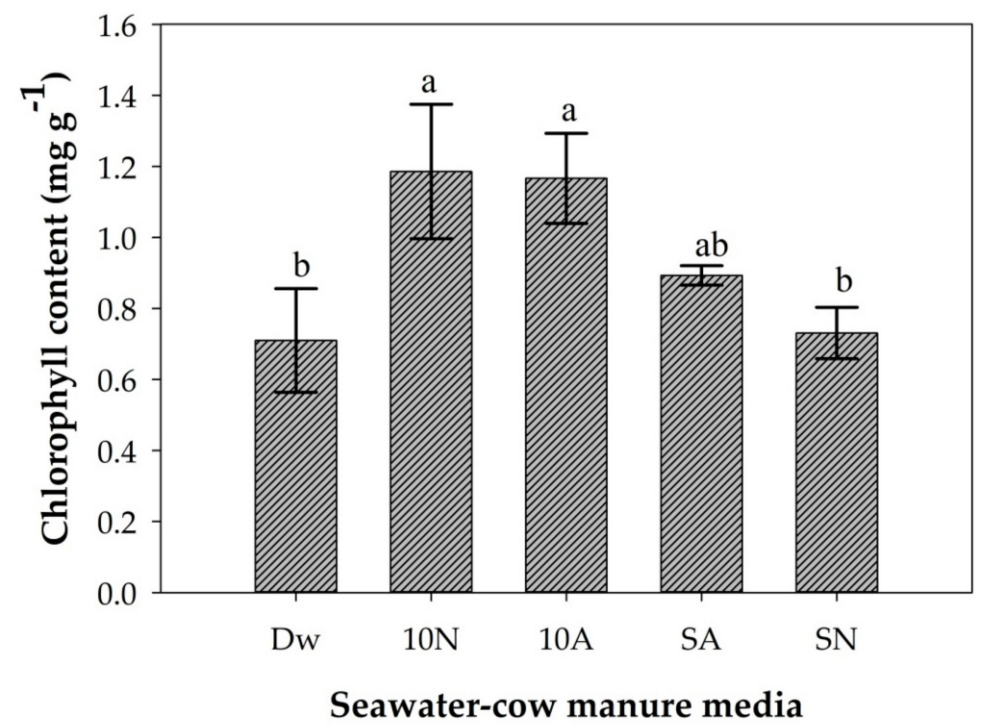

Figure 7. Effect of natural and artificial seawater with cow manure on the chlorophyll content of salt-tolerant cyanobacteria $(\mathrm{HSaC})$. $\mathrm{DW}=$ distilled water with cow manure, $10 \mathrm{~N}=$ natural seawater $(\mathrm{EC}, 10 \mathrm{dS} / \mathrm{m})$ with cow manure, $10 \mathrm{~A}=$ artificial seawater $(\mathrm{EC}, 10 \mathrm{dS} / \mathrm{m})$ with cow manure, $\mathrm{SA}=$ artificial seawater with cow manure and $\mathrm{SN}$ = natural seawater with cow manure. The error bars represent standard deviations (SDs). The data are the mean of three replicates. Differing letters indicate significant differences in means of $\mathrm{HSaC}$ cyanobacterial chlorophyll content in pair wise comparisons (Tukey's test $p<0.05$ ) for each treatment by LSD. 
The photosynthetic pigment (chlorophyll a) content (Figure S3) and biomass yield (Figure 8) of cyanobacterial strain LC were significantly $(p<0.05)$ different among the cow manure-seawater media treatments. The highest biomass yield $(35.47 \mathrm{mg} / \mathrm{mL})$ of strain LC was obtained from cow manure with diluted natural seawater at an EC of $0.5 \mathrm{dS} / \mathrm{m}$, while the lowest value $(10.66 \mathrm{mg} / \mathrm{mL})$ was from cow manure with diluted seawater at an EC of $1.5 \mathrm{dS} / \mathrm{m}$ (Figure 8).

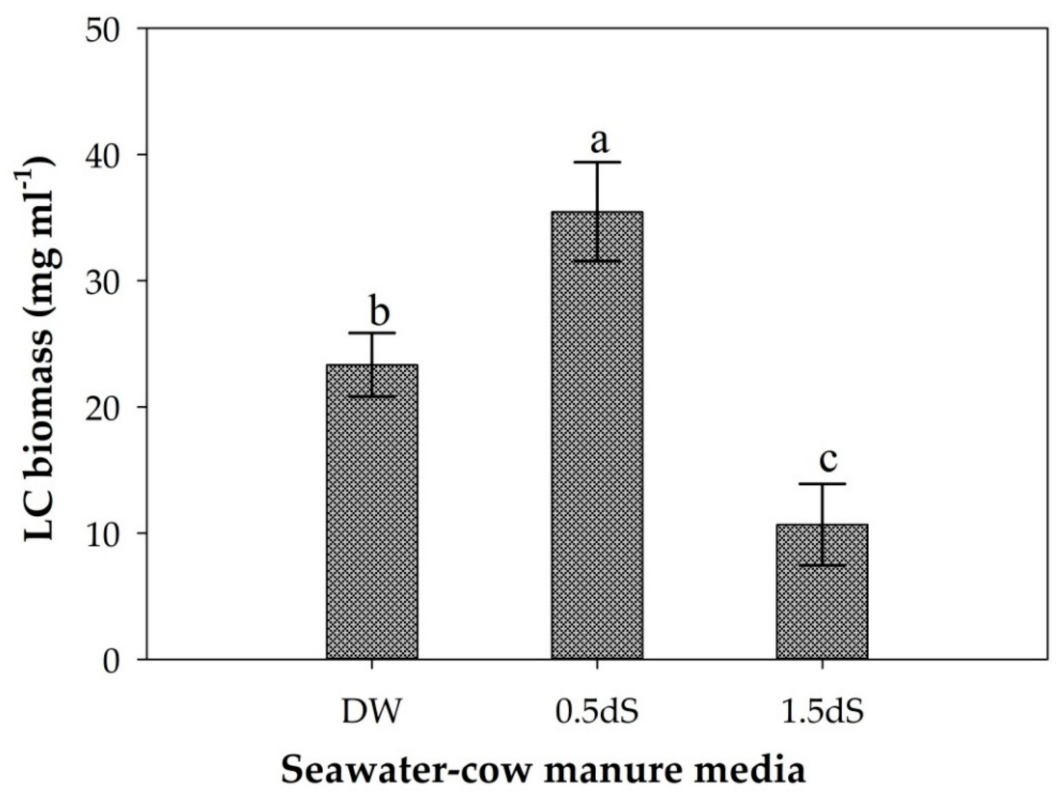

Figure 8. Effect of natural seawater and cow manure media on salt sensitive cyanobacteria (LC) biomass production. $\mathrm{DW}=$ cow manure with distilled water, $0.5 \mathrm{dS}=$ cow manure with natural seawater at an EC of $0.5 \mathrm{dS} / \mathrm{m}, 1.5 \mathrm{dS}=$ cow manure with natural seawater at an EC of $1.5 \mathrm{dS} / \mathrm{m}$. The error bars represent standard deviation (SD). The data are the mean of three replicates. Differing letters indicate significant differences of means of LC cyanobacterial biomass production in pairwise comparisons (Tukey's test $p<0.05$ ) for each treatment by LSD.

\section{Discussion}

\subsection{Effect of $\mathrm{NaCl}$ Salt Concentration on Growth of Cyanobacterial Strain HSaC}

The salinity tolerance capacity for the obtained cyanobacterial strain $\mathrm{HSaC}$ was tested. The biomass of the fresh weight increased from $0 \mathrm{mM} \mathrm{NaCl}$ salt concentration to $120 \mathrm{mM}$. Although the maximum biomass yield was obtained at $120 \mathrm{mM}$, a further increase in salt concentration resulted in a higher biomass yield than that at $0 \mathrm{mM} \mathrm{NaCl}$ concentration (Figure 1). This finding shows that the current tested cyanobacterial strain $\mathrm{HSaC}$ is a salt-loving microorganism. Gabbay and Tel-Or [25] conducted an experiment on marine spirulina to study the biochemical and physiological indicators of salinity tolerance. The authors reported that an increased cell growth rate in hypersaline medium suggested that the organism is salt-loving rather than salt-resistant.

The fact that the highest biomass yield, chlorophyll a and carotenoid contents were obtained at $120 \mathrm{mM} \mathrm{NaCl}$ salt concentration indicated that $120 \mathrm{mM}$ is a threshold $\mathrm{NaCl}$ salt concentration for improved growth and development of cyanobacterial strain $\mathrm{HSaC}$. Although further increasing the salt concentration from $120 \mathrm{mM}$ to $300 \mathrm{mM}$ resulted in a reduction in the chlorophyll a and carotenoid contents, increasing the salt concentration from $0 \mathrm{mM}$ to $120 \mathrm{mM}$ significantly increased the photosynthetic pigment content (Figure 3 and Figure S1).

The highest exo-polysaccharide (EPS) content was obtained at $180 \mathrm{mM} \mathrm{NaCl}$ concentration, which is unlike the results of biomass yield and photosynthetic pigments, whose contents peaked at $120 \mathrm{mM}$ (Figure 2). This behavior could probably result from the cells having invested more energy in EPS production than in cell division at $180 \mathrm{mM}$ salt concentration, and less energy in EPS production than 
in cell division at $120 \mathrm{mM}$ salt concentration. As the salt concentration increased, the EPS production also increased until the threshold level, but further increases in salinity reduced the EPS content. Similarly, Zou et al. [34] explained that, an increase in salt concentration increased the microbial EPS production, and a high salinity decreased EPS production in micro-organisms. In another study [35], it was reported that the EPS content increased with an increase in $\mathrm{NaCl}$ from $52.3 \mathrm{mg} \cdot \mathrm{L}^{-1}$ to $62 \mathrm{mg} \cdot \mathrm{L}^{-1}$ in the culture. A similar study [36] stated that the production of cyanobacterial exopolysaccharides (EPSs) was found to be stimulated by salts. This increase in EPS might be because EPSs on the cell membrane help cyanobacteria to maintain the osmotic balance or the excess flow of salt ions into the cell. Arora et al. [36] concluded that the increased EPSs had a strong ability to remove $\mathrm{Na}+$ from the cyanobacterial culture solution. It has been suggested that the accumulation of EPSs on the bacterial cell membrane is a protective response against salinity stress [34].

\subsection{Growth Response of Cyanobacterial Strains HSaC and LC to Manure and Seawater Media}

The $\mathrm{pH}$ of cow manure, chicken manure and pig manure media before cyanobacterial culture were not similar (Figure 4). This difference in $\mathrm{pH}$ could be mainly dependent on the feed that the animals consume and the acidic ion concentration in the manures. Chicken (poultry) manure is rich in $\mathrm{N}$ [26], which contributes to acid formation. After the culture had grown for 21 days, the $\mathrm{pH}$ increased in the cow manure compared to the $\mathrm{pH}$ pre-culturing, while no change in the chicken manure and little change in the pig manure was observed. The increase in $\mathrm{pH}$ has a direct relationship to the growth of the cyanobacteria, because they utilize more $\mathrm{CO}_{2}$ for photosynthesis, which can be used as a substrate for carbonic acid production and lowering the $\mathrm{pH}$ value. Pandey et al. [37] reported that determining the $\mathrm{pH}$ of growth culture media could be an indirect way to determine the potential cell growth of Spirulina platensis.

Cow manure with $10 \mathrm{dS} / \mathrm{m}$ diluted seawater showed the highest biomass production among all treatments (Figure 5). The higher biomass production in all treatments of cow manure-seawater than in chicken and pig manure treatments might be due to the optimum macro and micro nutrient distribution in cow manure. The biochemical analysis of anaerobic digester effluent from cattle waste product has shown the existence of micronutrients that sustainably support the growth of cyanobacteria [22]. Chinnasamy et al. [8] stated that most animal wastes such as livestock manure contain the essential nutrients to provide productive microalgal growth, and can be used as economically feasible algae growth media. Kebede-Westhead et al. [9] reported that, when the loading rate of anaerobically digested cow manure effluent increased, the productivity of algal biomass increased significantly to up to $16.5 \mathrm{~g}$ dry weight $\mathrm{m}^{-2} \mathrm{~d}^{-1}$, however, although the loading rate of anaerobically digested pig manure effluent increased, the productivity of algal biomass remained less than $10 \mathrm{~g}$ dry weight $\mathrm{m}^{-2} \mathrm{~d}^{-1}$.

Increased antibiotic concentrations in the pig and poultry manure could be another reason for the low biomass yield from pig and poultry manures compared to cow manure. This idea is supported by Zhang et al. [38] who stated that soil treated with pig manure and poultry manure resulted in a high antibiotic resistance genes (ARGs) content compared to that in cow manure and a control. In this current study, the biomass from cow manure-seawater media is higher than or equal to the biomass from the BG11 (reference cyanobacterial growth medium). In another experiment, Kobayashi et al. [22] grew different chlorella strains of microalgae in $10 \%$ anaerobic digester effluent, which was obtained from cattle manure, and this growth was compared with the growth of algae cultured in Bold's Basal Medium. The results confirmed that the biomass produced from chlorella strains in anaerobic digester effluent of cattle manure was similar to or greater than $280 \mathrm{mg} / \mathrm{L}$, which was the amount produced in Bold's Basal Medium in 21 days. In the current study, although pig and poultry manures suppressed cyanobacterial growth, they have performed well in other experiments for microalgal biomass production. Singh et al. [11] conducted an experiment on the growth of four microalgae strains, including chlorella in anaerobic digestion effluent (ADE) from poultry waste. The authors reported increased biomass production from the ADE, which resulted in high levels of protein $(39 \% w / w)$ and carbohydrate $(22 \% w / w)$. The report of Wang et al. [39] explained that the extract of poultry litter has 
the capacity to yield up to $180 \%$ more algal biomass as compared to artificial fertilizer growth medium. Effluent with reduced phosphorous and nitrogen content yielded increased fatty acid content $(7.5-11 \%)$ and biomass production of chlorella species, even though fermented pig manure with various chemical additions was used as the substrate [24].

The results of comparing natural and artificial seawater with cow manure media did not show a significant $(p<0.05)$ difference between the $10 \mathrm{~N}$ and $10 \mathrm{~A}$ treatments for cyanobacterial strain HSaC biomass production, chlorophyll a and carotenoid content (Figure 6, Figure 7 and Figure S2). However, as compared to other treatments, like SN, SA and DW, a significant difference was observed among the treatments. Therefore, in both natural and artificial seawaters with cow manure media, the highest biomass yield, chlorophyll a, and carotenoid content were recorded in the cow manure with diluted $(10 \mathrm{dS} / \mathrm{m})$ seawater medium (Figure 6, Figure 7 and Figure S2). This result suggested that both artificial and natural seawater at similar diluted salt concentrations can be used interchangeably as a potential source of cyanobacterial growth media in combination with cow manure. The biomass yield and photosynthetic pigment contents showed a strong correlation in the current experiment, but we found a weak correlation in treatment $\mathrm{SN}$, that is, the biomass yield showed a higher decrement as compared to photosynthetic pigment (Figures 6 and 7). This weak correlation between biomass yield and photosynthetic pigment content could be because high salt concentrations $(76.0 \mathrm{dS} / \mathrm{m})$ in natural seawater influenced cyanobacterial cell division more than the photosynthetic pigment content. Unlike in artificial seawater, which has a low salt concentration $(42.3 \mathrm{dS} / \mathrm{cm})$, in natural seawater, cyanobacterial cells likely invested more energy in cell protection (maintaining the health of cells and photosynthetic pigments) than in cell division, which resulted in a decreased biomass yield and increased photosynthetic pigment content (Figures 6 and 7). In addition, the high heavy metal concentration in our natural seawater [32] might have influenced cyanobacterial cell division more than it influenced photosynthetic pigments.

To identify the optimum growth conditions for the salt-sensitive cyanobacterial strain LC, experiments were conducted on media with a low salinity concentration of natural seawater and cow manure, and the highest values of biomass production and chlorophyll a content were recorded using $0.5 \mathrm{dS} / \mathrm{m}$ diluted seawater with cow manure medium (Figure 8).

\section{Conclusions}

In the current study, we developed a cost-effective cyanobacterial growth media from integrated manure-seawater nutrients for sustainable cyanobacterial biomass production. Before we tested seawater as a nutrient source, we evaluated the growth of the salt-tolerant cyanobacterial strain $\mathrm{HSaC}$ at different $\mathrm{NaCl}$ concentrations. Based on the results of the salinity test, we conducted an experiment to evaluate different animal manures, namely, cow manure, pig manure and chicken manure in different salt concentrations of seawater. According to the results, cow manure integrated with $10 \mathrm{dS} / \mathrm{m}$ diluted seawater showed the highest biomass production for salt-tolerant cyanobacterial strain $\mathrm{HSaC}$, and cow manure with $0.5 \mathrm{dS} / \mathrm{m}$ diluted seawater showed the best biomass yield for salt sensitive cyanobacterial strain LC. The results from integrated cow manure-seawater media were better than or similar to the results from the reference growth media (BG11). However, other animal manures, such as pigs and chickens, exhibited low biomass yield. The biomass production and photosynthetic pigment contents resulting from cow manure with natural seawater and cow manure with artificial seawater did not show a significant difference between $10 \mathrm{~N}$ and $10 \mathrm{~A}$. The results indicated that both natural seawater and artificial seawater at similar dilution can be used interchangeably for biomass production. Overall, the research findings from the current experiment suggested that cyanobacterial biomass produced from integrated cow manure-seawater media could be used for cyanobacterial biofertilizer and biofuel, which are important for improving soil fertility and energy production, respectively. This study will help smallholder farmers to produce their own cyanobacterial biofertilizer, and to produce energy from biofuel with cheap growth media. For more sustainable biomass production, further research should be conducted using different animal manures in combination with seawater. 
Supplementary Materials: The following are available online at http://www.mdpi.com/2076-3417/9/18/3888/s1, Figure S1: HSaC cyanobacterial carotenoid content as influenced by different $\mathrm{NaCl}$ salt concentration, Figure S2: The effect of cow manure-seawater growth media on carotenoid content of salt tolerant cyanobacteria (HSaC), Figure S3: Chlorophyll content of salt sensitive cyanobacteria (LC) under seawater-cow manure growth media.

Author Contributions: M.Y.S. developed the study design, carried out the experiments, created the original draft, revised the manuscript, and prepared the final version.

Funding: This work was supported by the Key Research Program (KFZD-SW-112) and STS Program (KFJ-STS-ZDTP-053) of Chinese Academy of Sciences, CAS-TWAS President's PhD Fellowship Program for International Students (Mekiso Yohannes Sido).

Conflicts of Interest: The author declare no conflict of interest.

\section{References}

1. Castrd, G.F.P.S.; Rizzd, R.F.; Passds, T.S.; Santds, B.N.C.; Dias, D.D. Biomass production by Arthrospira platensis under deferent culture conditions. Food Sci. Tech. 2015, 35, 18-24. [CrossRef]

2. $\mathrm{Hu}, \mathrm{Q}$. Industrial Production of Microalgal Cell-Mass and Secondary Products-Major Industrial Species: Arthrospira (Spirulina) Platensis. In Handbook of Microalgal Culture: Biotechnology and Applied Phycology; Richmond, A., Ed.; Blackwell Publishing: Oxford, UK, 2004; pp. 264-272.

3. Pathak, J.; Rajneesh; Maurya, P.K.; Singh, S.P.; Häder, D.P.; Sinha, R.P. Cyanobacterial Farming for Environment Friendly Sustainable Agriculture Practices: Innovations and Perspectives. Front. Environ. Sci. 2018, 6, 7. [CrossRef]

4. Markou, G.; Vandamme, D.; Muylaert, K. Microalgal and cyanobacterial cultivation: The supply of nutrients. Water Res. 2014, 65, 186-202. [CrossRef] [PubMed]

5. Benedetti, M.; Vecchi, V.; Barera, S.; Dall'Osto, L. Biomass from microalgae: The potential of domestication towards sustainable biofactories. Microb. Cell Factories 2018, 17, 173. [CrossRef] [PubMed]

6. Piorreck, M.; Baasch, K.H.; Pohl, P. Biomass production, total protein, chlorophylls, lipids and fatty acids of freshwater green and blue-green algae under different nitrogen regimes. Phytochemistry 1984, 23, 207-216. [CrossRef]

7. Mahadevaswamy, M.; Venkataraman, L. Bioconversion of poultry droppings for biogas and algal production. Agric. Wastes 1986, 18, 93-101. [CrossRef]

8. Chinnasamy, S.; Bhatnagar, A.; Claxton, R.; Das, K. Biomass and bioenergy production potential of microalgae consortium in open and closed bioreactors using untreated carpet industry effluent as growth medium. Bioresour. Technol. 2010, 101, 6751-6760. [CrossRef] [PubMed]

9. Kebede-Westhead, E.; Pizarro, C.; Mulbry, W.W. Treatment of swine manure effluent using freshwater algae: Production, nutrient recovery, and elemental composition of algal biomass at four effluent loading rates. Environ. Biol. Fishes 2006, 18, 41-46. [CrossRef]

10. Wilkie, M.P. Ammonia excretion and urea handling by fish gills: Present understanding and future research challenges. J. Exp. Zool. 2002, 293, 284-301. [CrossRef] [PubMed]

11. Singh, M.; Reynolds, D.L.; Das, K.C. Microalgal system for treatment of effluent from poultry litter anaerobic digestion. Bioresour. Technol. 2011, 102, 10841-10848. [CrossRef] [PubMed]

12. Bae, J.H.; Hur, S.B. Development of Economical Fertilizer-Based Media for Mass Culturing of Nannochloropsis oceanic. Fish. Aquat. Sci. 2011, 14, 317-322.

13. Jimenez-Perez, M.V.; Sanchez-Castillo, P.; Romera, O.; FernandezMoreno, D.; Perez-Martinez, C. Growth and nutrient removal in free and immobilized plantonic green algae isolated from pig manure. Enzyme Microb. Technol. 2004, 34, 392-398. [CrossRef]

14. Costa, R.H.; Medri, W.; Perdomo, C.C. High-rate pond for treatment of piggery wastes. Water Sci. Technol. 2000, 42, 357-362. [CrossRef]

15. Olguin, E.J.; Galicia, S.; Angulo-Guerrero, O.; Hernandez, E. The effect of low light flux and nitrogen deficiency on the chemical composition of Spirulina sp. (Arthrospira) grown on digested pig waste. Bioresour. Technol. 2001, 77, 19-24. [CrossRef]

16. Olguín, E.J. Phycoremediation: Key issues for cost-effective nutrient removal processes. Biotechnol. Adv. 2003, 22, 81-91. [CrossRef]

17. Ayala, B. Animal wastes media for Spirulina production. Arch. Hydrobiol. 1984, 67, 349-355. [CrossRef] 
18. Ak, I.; Cetin, Z.; Cirik, S. Gracilaria verrucosa (Hudson) Papenfuss culture using an agricultural organic fertilizers. Fresen. Environ. Bull. 2011, 20, 2156-2162.

19. Raoof, B.; Kaushik, B.; Prasanna, R. Formulation of a low-cost medium for mass production of Spirulina. Biomass Bioenergy 2006, 30, 537-542. [CrossRef]

20. Werlinger, C.; Mansilla, A.; Villarroel, A. Effects of Photon Flux Density and Agricultural Fertilizers on the Development of Sarcothalia Crispata Tetraspores (Rhodophyta, Gigartinales) from the Strait of Magellan, Chile. In Nineteenth International Seaweed Symposium Developments in Applied Phycology; Borowitzka, A.M., Critchley, A.T., Kraan, S., Peters, A., Sjøtun, K., Notoya, M., Eds.; Springer: Dordrecht, The Netherlands, 2007; Volume 2.

21. Zarrouk, C. Contribution a Letude d'une Cyanophycee. Influence de Divers Factours Physiques. Et Chimiques sur la Croissance et la Phytosynthese do Spirulina Maxima. Ph.D. Thesis, University of Paris, Paris, France, 1966.

22. Kobayashi, N.; Noel, E.A.; Barnes, A.; Watson, A.; Rosenberg, J.N.; Erickson, G.; Oyler, G.A. Characterization of three Chlorella sorokiniana strains in anaerobic digested effluent from cattle manure. Bioresour. Technol. 2013, 150, 377-386. [CrossRef]

23. Mulbry, W.; Westhead, E.K.; Pizarro, C.; Sikora, L. Recycling of manure nutrients: Use of algal biomass from dairy manure treatment as a slow release fertilizer. Bioresour. Technol. 2005, 96, 451-458. [CrossRef]

24. Hu, B.; Min, M.; Zhou, W.; Du, Z.; Mohr, M.; Chen, P.; Zhu, J.; Cheng, Y.; Liu, Y.; Ruan, R. Enhanced mixotrophic growth of microalga Chlorella sp. on pretreated swine manure for simultaneous biofuel feedstock production and nutrient removal. Bioresour. Technol. 2012, 126, 71-79. [CrossRef] [PubMed]

25. Gabbay, R.; Tel-Or, E. Cyanobacterial biomass production in saline media. Plant Soil 1985, 89, $107-116$. [CrossRef]

26. Chang, S.; Lee, Y. Comparison of two chemical extraction methods for proteins and polysaccharides of Spirogyra fluviatilis in extracellular polymeric substances. IOP Conf. Ser. Earth Environ. Sci. 2017, 64, 012122. [CrossRef]

27. Dubois, M.; Gilles, K.A.; Hamilton, J.K.; Rebers, P.A.; Smith, F. Colorimetric Method for Determination of Sugars and Related Substances. Anal. Chem. 1956, 28, 350-356. [CrossRef]

28. Zavřel, T.; Sinetova, M.A.; Červený, J. Measurement of Chlorophyll a and Carotenoids Concentration in Cyanobacteria. Bio-Protocol 2015, 5, e1467. [CrossRef]

29. Ritchie, J.R. Consistent sets of spectrophotometric chlorophyll equations for acetone, methanol and ethanol solvents. Photosynth. Res. 2006, 89, 27-41. [CrossRef]

30. Wellburn, R.A. The spectral determination of chlorophylls a and $b$, as well as total, carotenoids, using various solvents with spectrophotometers of different resolution. J. Plant Physiol. 1994, 144, 307-313. [CrossRef]

31. Chen, H.; Zheng, B. Sources of fluorescent dissolved organic matter in high salinity seawater (Bohai Bay, China). Environ. Sci. Pollut. Res. 2012, 20, 1762-1771. [CrossRef]

32. Wang, H.W.; Cai, D.B.; Yin, R.; Dong, Y.J.; Liu, X.; Gao, H.Q.; Zhao, W.; Zhu, N. The Evaluation of Heavy Metals in Seawater of the Oil Spill Area in Bohai Bay (China) during the Summer. Adv. Mater. Res. 2014, 1073, 500-503. [CrossRef]

33. Li, S.; Liu, R.; Shan, H. Nutrient Contents in Main Animal Manures in China. J. Agro. Environ. Sci. 2009, 28, 179-184.

34. Zou, X.; Xu, K.; Ding, L.; Ren, H. Effect of salinity on extracellular polymeric substances (EPS) and soluble microbial products (SMP) in anaerobic sludge systems. Fresen. Environ. Bull. 2009, 18, 1456-1461.

35. Zhang, L.H.; Tian, R.; Guo, J.B.; Jia, Y.P.; Zhang, H.F.; Li, Z.; Chen, Z.C. Effect of NaCl Salinity on Extracellular Polymeric Substances and Bioflocculation of Anoxic Sludge in A2/O Process. Huan Jing Ke Xue 2018, 39, 4281-4288. [CrossRef]

36. Arora, M.; Kaushik, A.; Rani, N.; Kaushik, C.P. Effect of cyanobacterial exopolysaccharides on salt stress alleviation and seed germination. J. Environ. Biol. 2010, 31, 701-704. [PubMed]

37. Pandey, J.P.; Neeraj, P.; Amit, T. Standardization of $\mathrm{pH}$ and Light Intensity for the Biomass Production of Spirulina platensis. J. Gen. Microbiol. 2010, 1, 93-102. 
38. Zhang, Y.J.; Hu, H.W.; Gou, M.; Wang, J.T.; Chen, D.; He, J.Z. Temporal succession of soil antibiotic resistance genes following application of swine, cattle and poultry manures spiked with or without antibiotics. Environ. Pollut. 2017, 231, 1621-1632. [CrossRef] [PubMed]

39. Bhatnagar, A.; Chinnasamy, S.; Singh, M.; Das, K. Renewable biomass production by mixotrophic algae in the presence of various carbon sources and wastewaters. Appl. Energy 2011, 88, 3425-3431. [CrossRef]

(C) 2019 by the author. Licensee MDPI, Basel, Switzerland. This article is an open access article distributed under the terms and conditions of the Creative Commons Attribution (CC BY) license (http://creativecommons.org/licenses/by/4.0/). 